\title{
咪唑基离子液体的物理化学性质估算及预测
}

\author{
刘青山 ${ }^{1} \quad$ 杨 氷 ${ }^{1} \quad$ 谭志诚 ${ }^{1,2, *}$ WELZ-BIERMANN Urs ${ }^{1, *}$ \\ ( ${ }^{1}$ 中国科学院大连化学物理研究所, 中国离子液体实验室, 辽宁大连 116023 ; \\ 2 中国科学院大连化学物理研究所, 热化学实验室, 辽宁大连 116023)
}

\begin{abstract}
摘要： 根据经验和半经验方程及空隙模型理论, 可以估算及预测离子液体在 $298.15 \mathrm{~K}$ 的物理化学性质. 本文 讨论了离子液体的分子体积, 密度, 标准熵, 晶格能, 表面张力, 等张比容, 摩尔蒸发焓, 空隙体积, 空隙率和热膨 胀系数. 通过实验测得的三种离子液体 1-乙基-3-甲基咪唑硫酸乙酯([ $\left.\left.\mathrm{C}_{2} \mathrm{mim}\right]\left[\mathrm{EtSO}_{4}\right)\right]$ ), 1-丁基-3-甲基咪唑硫酸辛 酯 ([ $\left.\mathrm{C}_{4} \mathrm{mim}\right]\left[\mathrm{OcSO}_{4}\right]$ )和 1-乙基-3-甲基咪唑双三氟甲磺酰亚胺盐( $\left[\mathrm{C}_{2} \mathrm{mim}\right]\left[\mathrm{NTf}_{2}\right]$ )的密度和表面张力估算了它们的 其它物理化学性质. 由这三种离子液体的分子体积及等张比容预测了同系列中其它离子液体 $\left[\mathrm{C}_{n} \mathrm{mim}\right]\left[\mathrm{EtSO}_{4}\right]$, $\left[\mathrm{C}_{n} \operatorname{mim}\right]\left[\mathrm{OcSO}_{4}\right]$ 和 $\left[\mathrm{C}_{n} \operatorname{mim}\right]\left[\mathrm{NTf}_{2}\right](n=1-6)$ 的分子体积及等张比容, 由此计算出它们的密度及表面张力. 进而预测 了它们的物理化学性质. 将预测的离子液体 $\left[\mathrm{C}_{4} \mathrm{mim}\right]\left[\mathrm{NTf}_{2}\right]$ 和 $\left[\mathrm{C}_{2} \mathrm{mim}\right]\left[\mathrm{OcSO}_{4}\right]$ 的密度值与文献报导的实验值进行 比较, 其偏差在实验误差范围内. 最后, 将由 $\mathrm{Kabo}$ 经验方程计算的七个离子液体 $\left[\mathrm{C}_{2} \mathrm{mim}\right]\left[\mathrm{EtSO}_{4}\right] 、\left[\mathrm{C}_{4} \mathrm{mim}\right]\left[\mathrm{OcSO}_{4}\right] 、$ $\left[\mathrm{C}_{2} \operatorname{mim}\right]\left[\mathrm{NTf}_{2}\right] 、\left[\mathrm{C}_{4} \operatorname{mim}\right]\left[\mathrm{NTf}_{2}\right]$ 、丁基三甲基铵双三氟甲磺酰亚胺盐([ $\left.\mathrm{N}_{4111}\right]\left[\mathrm{NTf}_{2}\right]$ 、甲基三辛基铵双三氟甲磺酰亚 胺盐([ $\left.\mathrm{N}_{8881}\right]\left[\mathrm{NTf}_{2}\right]$ )和 1-辛基-3-甲基吡啶四氟硼酸盐([ $\left.\mathrm{m}_{3} \mathrm{opy}\right]\left[\mathrm{BF}_{4}\right]$ )的摩尔蒸发焓与由 Verevkin 简单规则预测的 摩尔蒸发焓进行比较, 发现两者符合很好. 因此, 在缺乏密度和表面张力实验数据的情况下, 可以用 Verevkin 简 单规则来预测离子液体的摩尔蒸发焓.
\end{abstract}

关键词：离子液体；密度；表面张力；等张比容；蒸发焓；分子体积 中图分类号: $\mathrm{O} 642$

\section{Estimation and Prediction of the Physicochemical Properties of Imidazolium-Based Ionic Liquids}

\author{
LIU Qing-Shan ${ }^{1} \quad$ YANG Miao ${ }^{1} \quad$ TAN Zhi-Cheng ${ }^{1,2, *} \quad$ WELZ-BIERMANN Urs ${ }^{1, *}$ \\ $\left({ }^{1}\right.$ China Ionic Liquid Laboratory, Dalian Institute of Chemical Physics, Chinese Academy of Sciences, Dalian 116023, Liaoning \\ Province, P. R. China; ${ }^{2}$ Thermochemistry Laboratory, Dalian Institute of Chemical Physics, Chinese Academy of Sciences, \\ Dalian 116023, Liaoning Province, P. R. China)
}

\begin{abstract}
The physicochemical properties of ionic liquids (ILs) at $298.15 \mathrm{~K}$ could be estimated and predicted in terms of empirical and semi-empirical equations as well as by interstice model theory. In this paper, the molecular volume, density, standard molar entropy, lattice energy, surface tension, parachor, molar enthalpy of vaporization, interstice volume, interstice fraction, and thermal expansion coefficient are discussed. These properties were first estimated by experimentally determining the density and surface tension for 1-ethyl-3-methylimidazolium ethylsulfate $\left(\left[\mathrm{C}_{2} \mathrm{mim}\right]\left[\mathrm{EtSO}_{4}\right]\right)$, 1-butyl-3-methylimidazolium octylsulfate $\left(\left[\mathrm{C}_{4} \mathrm{mim}\right]\left[\mathrm{OcSO}_{4}\right]\right)$, and 1-ethyl-3-methylimidazolium bis(trifluoromethylsulfonyl)imide $\left(\left[\mathrm{C}_{2} \mathrm{mim}\right]\left[\mathrm{NTf}_{2}\right]\right)$. The molecular volume and parachor of the three homologues of the imidazolium-based ILs $\left[\mathrm{C}_{n} \mathrm{mim}\right]\left[\mathrm{EtSO}_{4}\right],\left[\mathrm{C}_{n} \mathrm{mim}\right]\left[\mathrm{OcSO}_{4}\right]$, and $\left[\mathrm{C}_{n} \operatorname{mim}\right]\left[\mathrm{NTf}_{2}\right](n=1-6)$ were predicted and their densities and surface tensions were obtained. Other properties were also calculated using the obtained density and surface tension values. The predicted density was compared to the experimental values for $\left[\mathrm{C}_{4} \operatorname{mim}\right]\left[\mathrm{NTf}_{2}\right]$ and $\left[\mathrm{C}_{2} \operatorname{mim}\right]\left[\mathrm{OcSO}_{4}\right]$, which shows that the deviation between experimental and predicted data are within experimental error. Finally, we compared the values for the molar enthalpy of vaporization estimated by Kabo's empirical equation with those predicted by Verevkin's simple rule for $\left[\mathrm{C}_{2} \mathrm{mim}\right]\left[\mathrm{EtSO}_{4}\right],\left[\mathrm{C}_{4} \mathrm{mim}\right]\left[\mathrm{OcSO}_{4}\right],\left[\mathrm{C}_{2} \mathrm{mim}\right]\left[\mathrm{NTf}_{2}\right],\left[\mathrm{C}_{4} \mathrm{mim}\right]\left[\mathrm{NTf} \mathrm{f}_{2}\right], N$-butyltrimethyla-
\end{abstract}

Received: November 9, 2009; Revised: February 2, 2010; Published on Web: April 9, 2010.

*Corresponding authors. Email: tzc@dicp.ac.cn, uwb@dicp.ac.cn

C. Editorial office of Acta Physico-Chimica Sinica 
mmonium bis(trifluoromethylsulfonyl)imide $\left[\mathrm{N}_{4111}\right]\left[\mathrm{NTf}_{2}\right], N$-methyltrioctylammonium bis(trifluoromethylsulfonyl)imide $\left(\left[\mathrm{N}_{8881}\right]\left[\mathrm{NTf}_{2}\right]\right)$, and $N$-octyl-3-methylpyridinium tetrafluoroborate $\left(\left[\mathrm{m}_{3} \mathrm{opy}\right]\left[\mathrm{BF}_{4}\right]\right)$ and found that the values obtained by these two equations were in good agreement with each other. Therefore, we suggest that the molar enthalpy of vaporization of ILs can be predicted by Verevkin's simple rule when experimental data for density and surface tension are not available.

Key Words: Ionic liquids; Density; Surface tension; Parachor; Enthalpy of vaporization; Molecular volume

ILs as organic salts, often exhibit interesting properties, such as low melting points, good solvation properties, and nonvolatility, which are required both by industrial and scientific communities for their broad application range as electrolytes in batteries and supercapacitors ${ }^{[-2]}$, reaction media in nanoscience ${ }^{[3]}$, physical chemistry ${ }^{[4-5]}$ and many other areas. Therefore, the data of physicochemical properties of ILs are fundamental for their future application and valuable for an insight into the origins of their unique behavior. Recently, more and more publications reported the experimental physicochemical properties of various $\mathrm{ILs}^{[6-15]}$. Although there is a significant amount of data related to imidazolium-based ILs, properties of homologue of $\left[\mathrm{C}_{n} \mathrm{mim}\right]$ $\left[\mathrm{EtSO}_{4}\right],\left[\mathrm{C}_{n} \mathrm{mim}\right]\left[\mathrm{OcSO}_{4}\right]$, and $\left[\mathrm{C}_{n} \mathrm{mim}\right]\left[\mathrm{NTf}_{2}\right](n=1-6)$ covered in this publication are still limited ${ }^{[16-17]}$. In this regard, we estimated various physicochemical properties of $\left[\mathrm{C}_{2} \mathrm{mim}\right]\left[\mathrm{EtSO}_{4}\right],\left[\mathrm{C}_{4} \mathrm{mim}\right]$ $\left[\mathrm{OcSO}_{4}\right]$, and $\left[\mathrm{C}_{2} \mathrm{mim}\right]\left[\mathrm{NTf}_{2}\right]$ by using their experimental density and surface tension data. In the next step, the physicochemical properties of their homologues $\left[\mathrm{C}_{n} \mathrm{mim}\right]\left[\mathrm{EtSO}_{4}\right],\left[\mathrm{C}_{n} \mathrm{mim}\right]\left[\mathrm{OcSO}_{4}\right]$, and $\left[\mathrm{C}_{n} \operatorname{mim}\right]\left[\mathrm{NTf}_{2}\right](n=1-6)$ were predicted from the estimated values of their molecular volumes and parachors. In the present paper, the ionic liquid cations are 1-alkyl-3-methylimidazolium $\left(\left[\mathrm{C}_{n} \text { mim }\right]^{+}\right)$, tetra-alkyl ammonium ([TAA $\left.]^{+}\right), N$-octyl-3-methylpyridinium $\left(\left[\mathrm{m}_{3} \mathrm{opy}\right]^{+}\right)$; the anions of the ILs are ethylsulfate ([EtSO $]_{4}^{-}$), octylsulfate $\left(\left[\mathrm{OcSO}_{4}\right]^{-}\right.$), bis (trifluoromethylsulfony) imide $\left(\left[\mathrm{NTf}_{2}\right]^{-}\right)$, and tetrafluoroborate $\left(\left[\mathrm{BF}_{4}\right]^{-}\right)$.

\section{Volumetric, entropy and lattice energy}

The molecular volume, $V_{\mathrm{m}}$, can be calculated from experimental density using the following equation:

$$
V_{\mathrm{m}}=M /(N \cdot \rho)
$$

where $M$ is molar mass, $\rho$ is density, and $N$ is Avogadro's constant.

According to Glasser's theory ${ }^{[18]}$, the standard molar entropy, $S^{\ominus}$, could be estimated from the following equation:

$S^{\ominus}(298.15 \mathrm{~K})=1246.5 V_{\mathrm{m}}+29.5$

The lattice energy, $U_{\text {POT, }}$ was estimated according to the following equation ${ }^{[18]}$ :

$$
U_{\text {POT }}(298.15 \mathrm{~K})=1981.2(\rho / M)^{1 / 3}+103.8
$$

The contribution methylene $\left(-\mathrm{CH}_{2}-\right)$ group to the molecular volume is $0.0272 \mathrm{~nm}^{3}$ for $\left[\mathrm{C}_{n} \operatorname{mim}\right]\left[\mathrm{BF}_{4}\right]^{[18]}, 0.0282 \mathrm{~nm}^{3}$ for $\left[\mathrm{C}_{n} \mathrm{mim}\right]\left[\mathrm{NTf}_{2}\right]^{[18]}, 0.0270 \mathrm{~nm}^{3}$ for $\left[\mathrm{C}_{n} \operatorname{mim}\right]\left[\mathrm{AlCl}_{4}\right]^{\left[{ }^{[5]}\right.}$, and 0.0278 $\mathrm{nm}^{3}$ for $\left[\mathrm{C}_{n} \mathrm{mim}\right][\mathrm{Ala}]^{[14]}$. Due to the similar values of the contribution of per $-\mathrm{CH}_{2}-$ to the molecular volume, the group of methylene in the alkyl chains of the imidazolium-based ILs could be considered to have the similar chemical environment. Hense, the mean value of the contribution can be calculated to be 0.0275 $\mathrm{nm}^{3}$, the physicochemical properties (density, standard entropy, lattice energy) of the homologues of $\left[\mathrm{C}_{n} \mathrm{mim}\right]\left[\mathrm{EtSO}_{4}\right]$ and $\left[\mathrm{C}_{n} \mathrm{mim}\right]$ $\left[\mathrm{OcSO}_{4}\right](n=1-6)$ could be predicted. Using the value $0.0282 \mathrm{~nm}^{3}$ for the contribution of per $-\mathrm{CH}_{2}-$ to the molecular volume for the homologues of $\left[\mathrm{C}_{n} \operatorname{mim}\right]\left[\mathrm{NTf}_{2}\right](n=1-6)^{[18]}$, the physicochemical properties of all IL homologues can be predicted. The calculated density value $\left(1.4381 \mathrm{~g} \cdot \mathrm{cm}^{-3}\right)$ for $\left[\mathrm{C}_{4} \mathrm{mim}\right]\left[\mathrm{NTf}_{2}\right]$ is in good agreement with the experimental values $\left(1.4366 \mathrm{~g} \cdot \mathrm{cm}^{-3}[\right.$ ] 1.43410 and $\left.1.43573 \mathrm{~g} \cdot \mathrm{cm}^{-3}{ }^{[19]}\right)$. The predicted density value $\left(1.0881 \mathrm{~g} \cdot \mathrm{cm}^{-3}\right)$ for $\left[\mathrm{C}_{2} \mathrm{mim}\right]\left[\mathrm{OcSO}_{4}\right]$ is also in good agreement with the experimental value of $1.0942 \mathrm{~g} \cdot \mathrm{cm}^{-3[20]}$.

All of these estimated and predicted physicochemical property data are listed in Tables 1-3.

Based on the plots of $S^{\ominus}$ against the number of the carbons, $n$, in the alkyl chain of the ILs (see Fig.1), the contribution of per methylene group to $S^{\ominus}$ was calculated to be $35.1 \mathrm{~J} \cdot \mathrm{K}^{-1} \cdot \mathrm{mol}^{-1}$ for $\left[\mathrm{C}_{n} \mathrm{mim}\right]\left[\mathrm{NTf}_{2}\right], 34.3 \mathrm{~J} \cdot \mathrm{K}^{-1} \cdot \mathrm{mol}^{-1}$ for $\left[\mathrm{C}_{n} \mathrm{mim}\right]\left[\mathrm{EtSO}_{4}\right]$, and 34.3 $\mathrm{J} \cdot \mathrm{K}^{-1} \cdot \mathrm{mol}^{-1}$ for $\left[\mathrm{C}_{n} \mathrm{mim}\right]\left[\mathrm{OcSO}_{4}\right]$. The above calculated values are in good agreement with the literature values of $35.1 \mathrm{~J} \cdot \mathrm{K}^{-1} \cdot \mathrm{mol}^{-1}$ for $\left[\mathrm{C}_{n} \mathrm{mim}\right]\left[\mathrm{NTf}_{2}\right]^{[18]}, 33.9 \mathrm{~J} \cdot \mathrm{K}^{-1} \cdot \mathrm{mol}^{-1}$ for $\left[\mathrm{C}_{n} \mathrm{mim}\right]\left[\mathrm{BF}_{4}\right]^{[18]}, 33.7$ $\mathrm{J} \cdot \mathrm{K}^{-1} \cdot \mathrm{mol}^{-1}$ for $\left[\mathrm{C}_{n} \mathrm{mim}\right]\left[\mathrm{AlCl}_{4}\right]^{[15]}$, and $34.6 \mathrm{~J} \cdot \mathrm{K}^{-1} \cdot \mathrm{mol}^{-1}$ for $\left[\mathrm{C}_{n} \mathrm{mim}\right][\mathrm{Ala}]^{[14]}$. According to these various values for the contribution of per methylene group to the standard molar entropy in the homologue series with different anions, it could be concluded that these contributions are relatively similar for all imidazolium-based ILs.

\section{Parachors and molar enthalpy of vaporization}

The parachor, $P$, was estimated from the following equation ${ }^{[2]}$ : $P=M \gamma^{1 / 4} / \rho$

where $\gamma$ is the surface tension.

According to literature ${ }^{[15]}$, the contribution of per methylene (- $\mathrm{CH}_{2}-$ ) group to parachor is 31.1. The values of parachors for the homologue series of the imidazolium-based ILs $\left[\mathrm{C}_{n} \mathrm{mim}\right]$ $\left[\mathrm{EtSO}_{4}\right],\left[\mathrm{C}_{n} \mathrm{mim}\right]\left[\mathrm{OcSO}_{4}\right]$, and $\left[\mathrm{C}_{n} \mathrm{mim}\right]\left[\mathrm{NTf}_{2}\right](n=1-6)$ were predicted.

The values of molar enthalpies of vaporization were estimated in terms of Kabo's empirical equation ${ }^{[22]}$ :

$\Delta_{\mathrm{l}}^{\mathrm{g}} H_{\mathrm{m}}^{\ominus}(298.15 \mathrm{~K})=0.01121\left(\gamma V^{2 / 3} N^{1 / 3}\right)+2.4$

where $V$ is molar volume.

According to Eq.(4), the surface tension can be calculated from predicted density and parachor data. The calculated value (31.71 $\mathrm{mJ} \cdot \mathrm{m}^{-2}$ ) for the surface tension of $\left[\mathrm{C}_{4} \mathrm{mim}\right]\left[\mathrm{NTf}_{2}\right]$ is in good agr- 
Table 1 Estimated and predicted values of physicochemical properties of $\left[\mathrm{C}_{n} \mathrm{mim}\right]\left[\mathrm{EtSO}_{4}\right](n=1-6)$ at $298.15 \mathrm{~K}$

\begin{tabular}{|c|c|c|c|c|c|c|c|c|c|c|c|c|}
\hline & $\frac{V_{\mathrm{m}}}{\mathrm{nm}^{3}}$ & $\frac{\rho}{\left(\mathrm{g} \cdot \mathrm{cm}^{-3}\right)}$ & $\frac{S^{\ominus}}{\left(\mathrm{J} \cdot \mathrm{K}^{-1} \cdot \mathrm{mol}^{-1}\right)}$ & $\frac{U_{\mathrm{pot}}}{\left(\mathrm{kJ} \cdot \mathrm{mol}^{-1}\right)}$ & $\frac{V}{\left(\mathrm{~cm}^{3} \cdot \mathrm{mol}^{-1}\right)}$ & $P$ & $\frac{\Delta_{1}^{\mathrm{g}} H_{\mathrm{m}}^{\ominus}}{\left(\mathrm{kJ} \cdot \mathrm{mol}^{-1}\right)}$ & $\frac{10^{24} v}{\mathrm{~cm}^{3}}$ & $\frac{\sum v}{\mathrm{~cm}^{3}}$ & $10^{2} \sum v / V$ & $\frac{10^{4} \alpha}{\mathrm{K}^{-1}}$ & $\frac{\gamma}{\left(\mathrm{mJ} \cdot \mathrm{m}^{-2}\right)}$ \\
\hline$\left[\mathrm{C}_{1} \mathrm{mim}\right]\left[\mathrm{EtSO}_{4}\right]^{\mathrm{b}}$ & 0.2880 & 1.2784 & 389.5 & 459 & 173.9 & 463.2 & 151.0 & 15.86 & 19.10 & 10.98 & 5.53 & 50.38 \\
\hline$\left[\mathrm{C}_{2} \mathrm{mim}\right]\left[\mathrm{EtSO}_{4}\right]^{\mathrm{a}}$ & 0.3163 & $1.2411^{[6]}$ & 423.7 & 448 & 190.4 & 494.3 & 144.7 & 18.52 & 22.30 & 11.71 & $5.89,5.58^{[6]}$ & $45.44^{[6]}$ \\
\hline$\left[\mathrm{C}_{3} \operatorname{mim}\right]\left[\mathrm{EtSO}_{4}\right]^{\mathrm{b}}$ & 0.3438 & 1.2094 & 458.0 & 439 & 207.0 & 525.4 & 139.9 & 21.19 & 25.52 & 12.33 & 6.20 & 41.53 \\
\hline$\left[\mathrm{C}_{4} \mathrm{mim}\right]\left[\mathrm{EtSO}_{4}\right]^{\mathrm{b}}$ & 0.3713 & 1.1826 & 492.3 & 430 & 223.5 & 556.5 & 136.3 & 23.82 & 28.68 & 12.83 & 6.45 & 38.42 \\
\hline$\left[\mathrm{C}_{5} \mathrm{mim}\right]\left[\mathrm{EtSO}_{4}\right]^{\mathrm{b}}$ & 0.3988 & 1.1593 & 526.6 & 423 & 240.1 & 587.6 & 133.6 & 26.38 & 31.76 & 13.23 & 6.66 & 35.89 \\
\hline$\left[\mathrm{C}_{6} \mathrm{mim}\right]\left[\mathrm{EtSO}_{4}\right]^{\mathrm{b}}$ & 0.4263 & 1.1393 & 560.9 & 416 & 256.6 & 618.7 & 131.5 & 28.89 & 34.78 & 13.55 & 6.82 & 33.78 \\
\hline
\end{tabular}

Table 2 Estimated and predicted values of physicochemical properties of $\left.\left[\mathrm{C}_{n} \mathrm{mim}_{[}\right] \mathrm{NTf}_{2}\right](n=1-6)$ at $298.15 \mathrm{~K}$

\begin{tabular}{|c|c|c|c|c|c|c|c|c|c|c|c|c|}
\hline & $\frac{V_{\mathrm{m}}}{\mathrm{nm}^{3}}$ & $\frac{\rho}{\left(\mathrm{g} \cdot \mathrm{cm}^{-3}\right)}$ & $\frac{S^{\ominus}}{\left(\mathrm{J} \cdot \mathrm{K}^{-1} \cdot \mathrm{mol}^{-1}\right)}$ & $\frac{U_{\mathrm{pot}}}{\left(\mathrm{kJ} \cdot \mathrm{mol}^{-1}\right)}$ & $\frac{V}{\left(\mathrm{~cm}^{3} \cdot \mathrm{mol}^{-1}\right)}$ & $P$ & $\frac{\Delta_{\mathrm{l}}^{\mathrm{g}} H_{\mathrm{m}}^{\ominus}}{\left(\mathrm{kJ} \cdot \mathrm{mol}^{-1}\right)}$ & $\frac{10^{24} v}{\mathrm{~cm}^{3}}$ & $\frac{\sum v}{\mathrm{~cm}^{3}}$ & $10^{2} \sum v / V$ & $\frac{10^{4} \alpha}{\mathrm{K}^{-1}}$ & $\frac{\gamma}{\left(\mathrm{mJ} \cdot \mathrm{m}^{-2}\right)}$ \\
\hline$\left[\mathrm{C}_{1} \mathrm{mim}\right]\left[\mathrm{NTf}_{2}\right]^{\mathrm{b}}$ & 0.3998 & 1.5676 & 527.9 & 422 & 240.7 & 598.7 & 142.6 & 23.94 & 28.82 & 11.98 & 6.02 & 38.29 \\
\hline$\left[\mathrm{C}_{2} \operatorname{mim}\right]\left[\mathrm{NTf}_{2}\right]^{\mathrm{a}}$ & 0.4280 & $1.5187^{[6]}$ & 563.0 & 415 & 257.7 & 629.8 & 139.2 & 26.59 & 32.01 & 12.43 & $6.25,6.66^{[6]}$ & $35.70^{[6]}$ \\
\hline$\left[\mathrm{C}_{3} \mathrm{mim}\right]\left[\mathrm{NTf}_{2}\right]^{\mathrm{b}}$ & 0.4562 & 1.4759 & 598.2 & 409 & 274.6 & 660.9 & 136.5 & 29.20 & 35.16 & 12.80 & 6.44 & 33.54 \\
\hline$\left[\mathrm{C}_{4} \mathrm{mim}\right]\left[\mathrm{NTf}_{2}\right]^{\mathrm{b}}$ & 0.4844 & 1.4381 & 633.3 & 403 & 291.6 & 692.0 & 134.4 & 31.76 & 38.24 & 13.11 & 6.60 & 31.71 \\
\hline$\left[\mathrm{C}_{4} \mathrm{mim}\right]\left[\mathrm{NTf}_{2}\right]^{\mathrm{a}}$ & 0.4849 & $1.4366^{[6]}$ & 633.9 & 402 & 291.9 & 698.6 & 139.0 & 30.19 & 36.35 & 12.45 & $6.27,6.73^{[6]}$ & $32.80^{[6]}$ \\
\hline$\left[\mathrm{C}_{4} \mathrm{mim}\right]\left[\mathrm{NTf}_{2}\right]^{\mathrm{a}}$ & 0.4857 & $1.43410^{[19]}$ & 635.0 & 402 & 292.4 & & & & & & & \\
\hline$\left[\mathrm{C}_{4} \mathrm{mim}\right]\left[\mathrm{NTf}_{2}\right]^{\mathrm{a}}$ & 0.4852 & $1.43573^{[19]}$ & 634.3 & 402 & 292.1 & & & & & & & \\
\hline$\left[\mathrm{C}_{5} \mathrm{mim}\right]\left[\mathrm{NTf}_{2}\right]^{\mathrm{b}}$ & 0.5126 & 1.4044 & 668.5 & 397 & 308.6 & 723.1 & 132.7 & 34.26 & 41.25 & 14.13 & 6.72 & 30.15 \\
\hline$\left[\mathrm{C}_{6} \operatorname{mim}\right]\left[\mathrm{NTf}_{2}\right]^{\mathrm{b}}$ & 0.5408 & 1.3743 & 703.6 & 392 & 325.6 & 754.2 & 131.4 & 36.70 & 44.18 & 14.32 & 6.83 & 28.80 \\
\hline
\end{tabular}

Table 3 Estimated and predicted values of the physicochemical properties of $\left[\mathrm{C}_{n} \mathrm{mim}_{[}\right]\left[\mathrm{OcSO} \mathrm{O}_{4}\right](n=1-6)$ at $298.15 \mathrm{~K}$

\begin{tabular}{|c|c|c|c|c|c|c|c|c|c|c|c|c|}
\hline & $\frac{V_{\mathrm{m}}}{\mathrm{nm}^{3}}$ & $\frac{\rho}{\left(\mathrm{g} \cdot \mathrm{cm}^{-3}\right)}$ & $\frac{S^{\ominus}}{\left(\mathrm{J} \cdot \mathrm{K}^{-1} \cdot \mathrm{mol}^{-1}\right)}$ & $\frac{U_{\mathrm{pot}}}{\left(\mathrm{kJ} \cdot \mathrm{mol}^{-1}\right)}$ & $\frac{V}{\left(\mathrm{~cm}^{3} \cdot \mathrm{mol}^{-1}\right)}$ & $P$ & $\frac{\Delta_{1}^{\mathrm{g}} H_{\mathrm{m}}^{\ominus}}{\left(\mathrm{kJ} \cdot \mathrm{mol}^{-1}\right)}$ & $\frac{10^{24} v}{\mathrm{~cm}^{3}}$ & $\frac{\sum v}{\mathrm{~cm}^{3}}$ & $10^{2} \sum v / V$ & $\frac{10^{4} \alpha}{\mathrm{K}^{-1}}$ & $\frac{\gamma}{\left(\mathrm{mJ} \cdot \mathrm{m}^{-2}\right)}$ \\
\hline$\left[\mathrm{C}_{1} \operatorname{mim}\right]\left[\mathrm{OcSO}_{4}\right]^{\mathrm{b}}$ & 0.4617 & 1.1025 & 605.0 & 407 & 277.9 & 651.5 & 124.1 & 34.19 & 41.17 & 14.81 & 7.45 & 30.19 \\
\hline$\left[\mathrm{C}_{2} \operatorname{mim}\right]\left[\mathrm{OcSO}_{4}\right]^{\mathrm{b}}$ & 0.4892 & 1.0881 & 639.3 & 402 & 294.5 & 682.6 & 123.3 & 36.58 & 44.05 & 14.96 & 7.52 & 28.86 \\
\hline$\left[\mathrm{C}_{2} \operatorname{mim}\right]\left[\mathrm{OcSO}_{4}\right]^{\mathrm{a}}$ & 0.4866 & $1.0942^{[20]}$ & 636.0 & 402 & 293.0 & & & & & & & \\
\hline$\left[\mathrm{C}_{3} \mathrm{mim}\right]\left[\mathrm{OcSO}_{4}\right]^{\mathrm{b}}$ & 0.5167 & 1.0753 & 673.6 & 396 & 311.1 & 713.7 & 122.8 & 38.86 & 46.79 & 15.04 & 7.57 & 27.72 \\
\hline$\left[\mathrm{C}_{4} \mathrm{mim}\right]\left[\mathrm{OcSO}_{4}\right]^{\mathrm{a}}$ & 0.5442 & $1.0638^{[6]}$ & 707.8 & 391 & 327.6 & 744.8 & 122.6 & 41.09 & 49.47 & 15.10 & $7.59,6.21^{[6]}$ & $26.71^{[6]}$ \\
\hline$\left[\mathrm{C}_{5} \mathrm{mim}\right]\left[\mathrm{OcSO}_{4}\right]^{\mathrm{b}}$ & 0.5717 & 1.0534 & 742.1 & 387 & 344.2 & 775.9 & 122.5 & 43.20 & 52.02 & 15.11 & 7.60 & 25.83 \\
\hline$\left[\mathrm{C}_{6} \operatorname{mim}\right]\left[\mathrm{OcSO}_{4}\right]^{\mathrm{b}}$ & 0.5992 & 1.0439 & 776.4 & 382 & 360.7 & 807.0 & 122.6 & 45.24 & 54.47 & 15.10 & 7.60 & 25.05 \\
\hline
\end{tabular}

${ }^{\mathrm{a}}$ Property data for this IL were estimated values; ${ }^{\mathrm{b}}$ property data for this IL were predicted values.

eement with the experimental value $\left(32.80 \mathrm{~mJ} \cdot \mathrm{m}^{-2}\right)^{[6]}$. The molar enthalpy of vaporization, $\Delta_{\uparrow}^{\mathrm{\rho}} H_{\mathrm{m}}^{\ominus}$, then can be obtained based on the predicted density and surface tension data.

All of these data are listed in Tables 1-4.

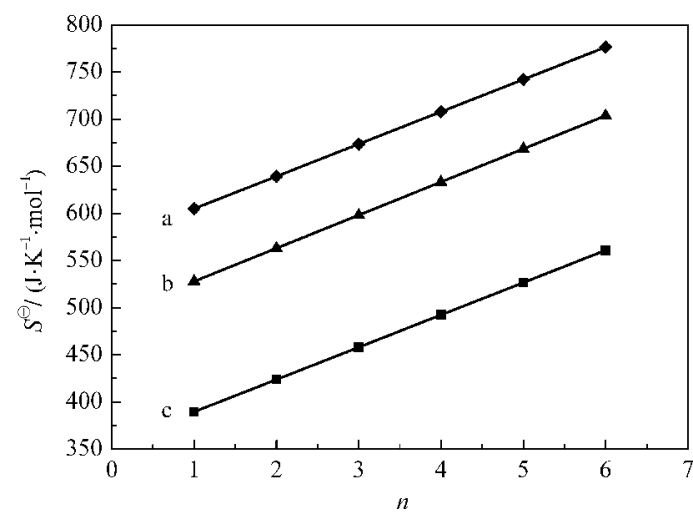

Fig.1 Plots of $S^{\ominus}$ against the number of the carbon $(n)$ in the alkyl chain of the ILs at $298.15 \mathrm{~K}$

(a) $S^{\ominus}=570.7+34.27 n, R=0.9999$ for $\left[\mathrm{C}_{n} \mathrm{mim}\right]\left[\mathrm{OcSO}_{4}\right]$;

(b) $S^{\ominus}=492.7+35.14 n, R=0.9999$ for $\left[\mathrm{C}_{n} \operatorname{mim}\right]\left[\mathrm{NTf}_{2}\right]$;

(c) $S^{\ominus}=355.2+34.29 n, R=0.9999$ for $\left[\mathrm{C}_{n} \mathrm{mim}\right]\left[\mathrm{EtSO}_{4}\right]$
The plots of density, $\rho$, and surface tension, $\gamma$, against the number of carbon, $n$, in alkyl chain of ILs at $298.15 \mathrm{~K}$ are shown in Figs.2 and 3.

From the Figs. 2 and 3, it can be seen that as for density: $\left[\mathrm{C}_{n} \mathrm{mim}\right]$ $\left[\mathrm{NTf}_{2}\right]>\left[\mathrm{C}_{n} \mathrm{mim}\right]\left[\mathrm{EtSO}_{4}\right]>\left[\mathrm{C}_{n} \mathrm{mim}\right]\left[\mathrm{OcSO}_{4}\right]$ and as for surface tension: $\left[\mathrm{C}_{n} \mathrm{mim}\right]\left[\mathrm{EtSO}_{4}\right]>\left[\mathrm{C}_{n} \mathrm{mim}\right]\left[\mathrm{NTf}_{2}\right]>\left[\mathrm{C}_{n} \operatorname{mim}\right]\left[\mathrm{OcSO}_{4}\right]$.

\section{Interstice model theory}

According to the interstice model ${ }^{[23-24]}$, the interstice volume, $v$, could be estimated by classical statistical mechanics:

$$
v=0.6791\left(k_{\mathrm{B}} T / \gamma\right)^{3 / 2}
$$

where $k_{\mathrm{B}}$ is the Boltzmann constant, $T$ is the thermodynamic temperature.

The molar volume of ionic liquids, $V$, consists of the inherent volume, $V_{i}$, and the volume of the interstice; whereas the molar volume of the interstice is $\sum v=2 N v$ :

$$
V=V_{i}+2 N v
$$

If the expansion volume of IL only results from the expansion of the interstice when the temperature increases, then, the thermal expansion coefficient, $\alpha$, can be predicted from the interstice model: 
Table 4 Values of the molar enthalpies of vaporization of ILs at $298.15 \mathrm{~K}$

\begin{tabular}{lccccc}
\hline & $\frac{\rho}{\left(\mathrm{g} \cdot \mathrm{cm}^{-3}\right)}$ & $\frac{\gamma}{\left(\mathrm{mJ} \cdot \mathrm{m}^{-2}\right)}$ & $\frac{\Delta_{1}^{\mathrm{g}} H_{\mathrm{m}}^{\ominus}}{\left(\mathrm{kJ} \cdot \mathrm{mol}^{-1}\right)}$ & $\frac{\Delta_{1}^{\mathrm{g}} H_{\mathrm{m}}^{\ominus}}{\left(\mathrm{kJ} \cdot \mathrm{mol}^{-1}\right)}$ \\
\hline$\left[\mathrm{C}_{2} \mathrm{mim}\right]\left[\mathrm{EtSO}_{4}\right]$ & $1.2411^{[6]}$ & $45.44^{[6]}$ & 158.8 & 144.7 \\
{$\left[\mathrm{C}_{2} \mathrm{mim}\right]\left[\mathrm{NTf}_{2}\right]$} & $1.5187^{[6]}$ & $35.70^{[6]}$ & 132.9 & 139.3 \\
{$\left[\mathrm{C}_{4} \mathrm{mim}\right]\left[\mathrm{NTf}_{2}\right]$} & $1.4366^{[6]}$ & $32.80^{[6]}$ & 137.9 & 139.0 \\
{$\left[\mathrm{C}_{4} \mathrm{mim}\right]\left[\mathrm{OcSO}_{4}\right]$} & $1.0638^{[6]}$ & $26.71^{[6]}$ & 178.8 & 122.5 \\
{$\left[\mathrm{~N}_{4111}\right]\left[\mathrm{NTf}_{2}\right]$} & $1.3940^{[6]}$ & $32.46^{[6]}$ & 136.2 & 135.3 \\
{$\left[\mathrm{~N}_{8281}\right]\left[\mathrm{NTf}_{2}\right]$} & $1.1046^{[6]}$ & $27.93^{[6]}$ & 181.2 & 187.8 \\
{$\left[\mathrm{~m}_{3} \mathrm{opy}^{[6]}\left[\mathrm{BF}_{4}\right]\right.$} & $1.0945^{[8]}$ & $36.51^{[8]}$ & $166.2^{\mathrm{a}}$ & $167.4^{\mathrm{b}}$ \\
\hline \multicolumn{4}{c}{${ }^{\mathrm{a}}$ data predicted from Eq.(9); ${ }^{\mathrm{b}}$ data estimated from Eq.(5) }
\end{tabular}

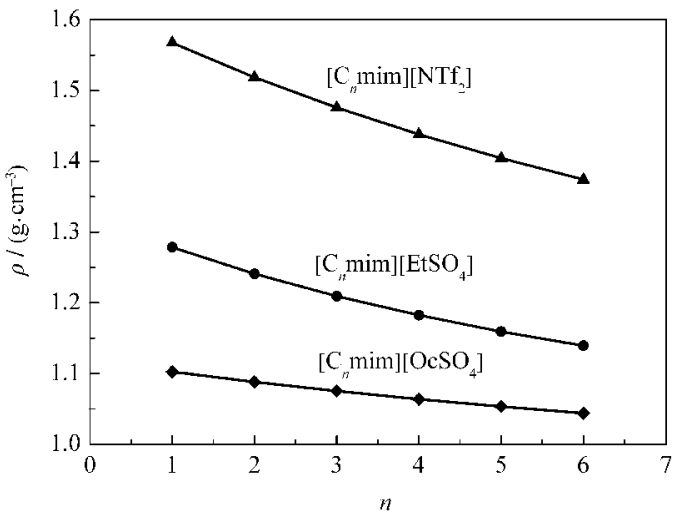

Fig.2 Plots of density $(\rho)$ against $n(n=1-6)$ at $298.15 \mathrm{~K}$

$$
\alpha=(1 / V)(\partial V / \partial T)_{p}=3 N v / V T
$$

All data obtained by this estimation and prediction are listed in Tables 1-3.

The prediction and estimation values of the thermal expansion coefficients in Tables 1-3 are in good agreement with experimental values. It also can be noticed that the values of interstice fractions, $\sum v / V$, differentiate only about $10 \%-15 \%$ for all ILs studied in the present article and these values are in good agreement with the values of volume expansion in the process from solid to liquid state for the majority of materials. Therefore the interstice model is applicable and the interstice model theory can be used to calculate the thermal expansion coefficient of imidazolium-based ILs.

\section{Prediction of enthalpy of vaporization}

Recently, Verevkin ${ }^{[25]}$ has published an article titled "Predicting enthalpy of vaporization of ionic liquids: a simple rule for a complex property", in which he predicted molar enthalpy of vaporization of ILs by a simple rule in case of lack of experimental data. He proposed the following simple rule:

$$
\Delta_{1}^{\mathrm{g}} H_{\mathrm{m}}^{\ominus}(\mathrm{IL})=\sum n_{i} \Delta H_{i}+\sum n_{j} \Delta H_{j}
$$

where $\Delta H_{i}$ is the contribution of the $i$ th element, $n_{i}$ is the number of the element of the $i$ th type in ILs, $\Delta H_{j}$ is the contribution of the $j$ th structural correction and $n_{j}$ is the number of the element of the $j$ th structural correction in ILs. The parameters ${ }^{[25]}$ for predicting the molar enthalpy of vaporization of ILs are listed in Table 5 .

Verevkin pointed out that "a special structural correction could
Table 5 Parameters for predicting the enthalpy of vaporization of ILs at 298.15 $\mathrm{K}^{[25]}$

\begin{tabular}{cccr}
\hline Parameter & Value & Parameter & Value \\
\hline$\Delta H_{\mathrm{C}} /\left(\mathrm{kJ} \cdot \mathrm{mol}^{-1}\right)$ & 2.5 & $\Delta H_{\mathrm{P}} /\left(\mathrm{kJ} \cdot \mathrm{mol}^{-1}\right)$ & 4.1 \\
$\Delta H_{\mathrm{N}} /\left(\mathrm{kJ} \cdot \mathrm{mol}^{-1}\right)$ & 26.3 & $\Delta H_{\mathrm{S}} /\left(\mathrm{kJ} \cdot \mathrm{mol}^{-1}\right)$ & -8.2 \\
$\Delta H_{\mathrm{O}} /\left(\mathrm{kJ} \cdot \mathrm{mol}^{-1}\right)$ & 23.6 & $\Delta H_{\mathrm{Cr}_{3}} /\left(\mathrm{kJ} \cdot \mathrm{mol}^{-1}\right)$ & -63.1 \\
$\Delta H_{\mathrm{B}} /\left(\mathrm{kJ} \cdot \mathrm{mol}^{-1}\right)$ & 23.0 & $\Delta H_{\text {ring }} /\left(\mathrm{kJ} \cdot \mathrm{mol}^{-1}\right)$ & 27.1 \\
$\Delta H_{\mathrm{F}} /\left(\mathrm{kJ} \cdot \mathrm{mol}^{-1}\right)$ & 13.7 & &
\end{tabular}

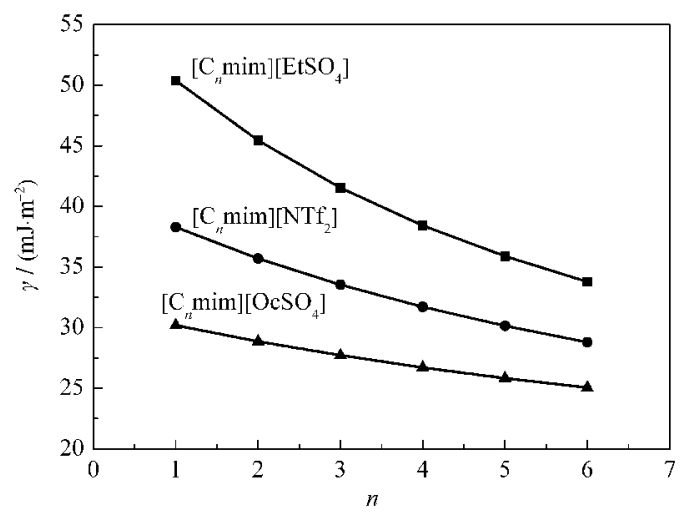

Fig.3 Plots of surface tension $(\gamma)$ against $n(n=1-6)$ at $298.15 \mathrm{~K}$

be also necessary for quaternary ammonium based ILs" ${ }^{[25]}$. Herein, the structure of the quaternary ammonium cation is regarded to be the ring of imidazolium cation, therefore, its structural correction parameter is $\Delta H=27.1 \mathrm{~kJ} \cdot \mathrm{mol}^{-1}$. The predicted data are listed in Table 4. From this table, the values of the molar enthalpies of vaporization, $\Delta_{\mathrm{l}}^{\mathrm{g}} H_{\mathrm{m}}^{\ominus}$, predicted by Eq.(9) are in good agreement with the values estimated by Eq.(5) except for [ $\left.\mathrm{C}_{4} \mathrm{mim}\right]$ $\left[\mathrm{OcSO}_{4}\right]$. This is because that the Eq.(5) is valid mainly for ILs $\left[\mathrm{C}_{n} \mathrm{mim}\right]\left[\mathrm{NTf}_{2}\right]$. Indeed, the assumption to consider the quaternary ammonium cation as a ring system needs confirmation.

\section{Conclusions}

The physicochemical properties (molecular volume, molar volume, parachor, interstice volume, interstice fraction, thermal expansion coefficient, standard entropy, lattice energy, and molar enthalpy of vaporization) of $\left[\mathrm{C}_{2} \mathrm{mim}\right]\left[\mathrm{EtSO}_{4}\right],\left[\mathrm{C}_{4} \mathrm{mim}\right]\left[\mathrm{OcSO}_{4}\right]$, and $\left[\mathrm{C}_{2} \mathrm{mim}\right]\left[\mathrm{NTf}_{2}\right]$ were estimated by using their experimental data of density and surface tension. Based on the estimated data of the molecular volume and parachor, the physicochemical properties (density, surface tension and all of the properties mentioned above) for their homologue series $\left[\mathrm{C}_{n} \mathrm{mim}\right]\left[\mathrm{EtSO}_{4}\right]$, $\left[\mathrm{C}_{n} \mathrm{mim}\right]\left[\mathrm{OcSO}_{4}\right]$, and $\left[\mathrm{C}_{n} \mathrm{mim}\right]\left[\mathrm{NTf}_{2}\right](n=1-6)$ were predicted.

We compared the values of molar enthalpies of vaporization for $\left[\mathrm{C}_{2} \mathrm{mim}\right]\left[\mathrm{EtSO}_{4}\right],\left[\mathrm{C}_{4} \mathrm{mim}\right]\left[\mathrm{OcSO}_{4}\right],\left[\mathrm{C}_{2} \mathrm{mim}\right]\left[\mathrm{NTf}_{2}\right],\left[\mathrm{C}_{4} \mathrm{mim}\right]$ $\left[\mathrm{NTf}_{2}\right],\left[\mathrm{N}_{4111}\right]\left[\mathrm{NTf}_{2}\right],\left[\mathrm{N}_{8881}\right]\left[\mathrm{NTf}_{2}\right]$, and $\left[\mathrm{m}_{3} \mathrm{opy}\right]\left[\mathrm{BF}_{4}\right]$, estimated by Kabo's empirical equation with those predicted by Verevkin's simple rule, and found that the values calculated in terms of the two approaches are in good agreement with each other. Hence, it is suggested that the molar enthalpy of vaporization of ILs could be estimated in terms of Verevkin's simple rule when the experimental data are not available. 


\section{References}

1 Tsunashima, K.; Sugiya, M. Electrochem. Commun., 2007, 9: 2353

2 Seki, S.; Kobayashi, Y.; Miyashiro, H.; Ohno, Y.; Usami, A.; Mita, Y.; Watanabe, M.; Terada, N. Chem. Commun., 2006: 544

3 Itoh, H.; Naka, K.; Chujo, Y. J. Am. Chem. Soc., 2004, 126: 3026

4 Du, Z.; Yu, Y. L.; Wang, J. H. Chem. Eur. J., 2007, 13: 2130

5 Endres, F.; Abedin, S. Z. E. Phys. Chem. Chem. Phys., 2006, 8 : 2101

6 Wandschneider, A.; Lehmann, J. K.; Heintz, A. J. Chem. Eng. Data, 2008, 53: 596

7 Bandres, I.; Giner, B.; Artigas, H.; Lafuente, C.; Royo, F. M. J. Chem. Eng. Data, 2009, 54: 236

8 Sun, J.; Forsyth, M.; MacFarlane, D. R. J. Phys. Chem. B, 1998, 102: 8858

9 Tokuda, H.; Hayamizu, K.; Ishii, K.; Susan, M. A. B. H.; Watanabe, M. J. Phys. Chem. B, 2004, 108: 16593

10 Tokuda, H.; Ishii, K.; Susan, M. A. B. H.; Tsuzuki, S.; Hayamizu, K.; Watanabe, M. J. Phys. Chem. B, 2006, 110: 2833

11 Bandrés, I.; Giner, B.; Artigas, H.; Royo, F. M.; Lafuente, C. J. Phys. Chem. B, 2008, 112: 3077

12 Tong, J.; Liu, Q. S.; Guan, W.; Yang, J. Z. J. Phys. Chem. B, 2007, 111: 3197

13 Tong, J.; Liu, Q. S.; Zhang, P.; Yang, J. Z. J. Chem. Eng. Data,
2007, 52: 1497

14 Fang, D. W.; Guan, W.; Tong, J.; Wang, Z. W.; Yang, J. Z. J. Phys. Chem. B, 2008, 112: 7499

15 Tong, J.; Liu, Q. S.; Xu, W. G.; Fang, D. W.; Yang, J. Z. J. Phys. Chem. B, 2008, 112: 4381

16 Fernández, A.; Torrecilla, J. S.; García, J.; Rodríguez, F. J. Chem. Eng. Data, 2007, 52: 1979

17 Fernández, A.; García, J.; Torrecilla, J. S.; Oliet, M.; Rodríguez, F. J. Chem. Eng. Data, 2008, 53: 1518

18 Glasser, L. Thermochim. Acta, 2004, 421: 87

19 Troncoso, J.; Cerdeirina, C. A.; Sanmamed, Y. A.; Romani, L.; Rebelo, L. P. N. J. Chem. Eng. Data, 2006, 51: 1856

20 Hasse, B.; Lehmann, J.; Assenbaum, D.; Wasserscheid, P.; Leipertz, A.; Froba, A. P. J. Chem. Eng. Data, 2009, 54: 2576

21 Deetlefs, M.; Seddon, K. R.; Shara, M. Phys. Chem. Chem. Phys., 2006, 8: 642

22 Zaitsau, D. H.; Kabo, G. J.; Strechan, A. A.; Paulechka, Y. U.; Tschersich, A.; Verevkin, S. P.; Heintz, A. J. Phys. Chem. A, 2006, 110: 7303

23 Yang, J. Z.; Lu, X. M.; Gui, J. S.; Xu, W. G. Green Chem., 2004, 6: 541

24 Zhang, Q. G.; Yang, J. Z.; Lu, X. M.; Gui, J. S.; Huang, M. Fluid Phase Equilib., 2004, 226: 207

25 Verevkin, S. P. Angew. Chem. Int. Edit., 2008, 47: 5071 